\title{
WATER MANAGEMENT IN SPAIN: AN EXAMPLE OF CHANGING PARADIGMS
}

\author{
Alberto Garrido and M.Ramón Llamas
}

\begin{abstract}
Spain's water policy has changed dramatically in the last twenty years. This rapid evolution has been accompanied by growing water problems. This paper reviews the recent history of Spanish water policy, examines its weaknesses and strengths and draws policy relevant conclusions for other arid and semiarid countries. Key drivers of change, including environmental degradation, growing water demand, climatic change, agricultural policy and economic growth. Among major water policy reforms are the water law reform in 1999, enabling water market transactions, the EU Water Framework Directive in 2000, the 2001 national hydrological plan and its subsequent reform in 2004. The paper concludes summarising the most outstanding lessons that the Spanish case can provide to water policy discussions at a global scale.
\end{abstract}

Authors Bio. Alberto garrido is an Associate Professor of Agricultural and Resource Economics at the Technical University of Madrid. His work focuses on natural resource and water economics and policy. Has conducted consultant work for OECD, IADB, European Parliament, European Commission, FAO, and various Spanish Ministries and Autonomous Communities. He is the author of 85 academic references.

Manuel R. Llamas is Emeritus Professor of Hydrogeology at the Complutense University of Madrid. Fellow of Spain's Royal Academy of Sciences, where he chairs the Section of Natural Sciences and the International Relations Committee. Author of one hundred books or monographs and almost two hundred scientific papers. President of the International Association of Hydrogeologists (1984-1989). Vice-president of the International Water Resources Association (2001-2003). Fellow of the European Academy of Sciences and Arts (2004)

Keywords for indexing. Spain, water policy, Water Framework Directive, Ebro, Guadiana, water markets, water pricing, groundwater, water law, Cidacos, costeffectiveness, irrigation, Tagus, inter-basin transfers, good ecological status, water rights, Catalonia, Andalusia, Castille-La Mancha, National Hydrological Plan. 


\section{Major water policy landmarks}

Spain's water policy has undergone a rapid process of piecemeal reforms, beginning in 1985, experiencing an 1999 and ending in 2007. In this section, we review them and summarise their main implications.

\subsection{The 1985 Water Law}

In many respects the 1985 Water Law (WL) forms the core of water legislation in present day in Spain. At the time it was enacted, it replaced the 1886 water law and its amended version in 1879. As Embid Irujo (2007) contends, the $1985 \mathrm{WL}$ opened a new era for water policy for a number of reasons: (i) water resources were considered public domain, saving a few exceptions of groundwater use (which, by the way, are part of the root of the problems related to groundwater use that this chapter also reviews); (ii) it laid down the water planning principles that eventually will be materialised in three failed attempts of national hydrological plans; (iii) it consolidated a financial regime for water users which delivered them important benefits, the irrigators being the most favoured; (iv) it consolidated the institutional role of the basin agencies, granting them autonomy, financial resources and personnel to become the actual decision makers in all water issues within the basin boundaries; lastly, (v) it defined a model of co-decision making in which direct water users and interested adminstrations have had an active role in all water planning and management at basin level.

\subsection{The 1999 Water Law reform}

This reform ammended the 1985 Water Law, changing three fundamental issues (Garrido, 2006; Ariño \& Sastre, 2008; Embid Irujo, 2008). First was the regulation of the exchange of water rights, permitting right-holders to engage in voluntary water transfers and the Basin Authorities (Organismos de Cuenca) to setup water banks or trading centers in cases of droughts or of severe scarcity problems. The second aspect focused on the new of public corporations in building water works and recouping the costs by means of sounder financial arrangements. The third was a subtle, but crucial consideration of desalinised and reused water as belonging to the public domain, on equal foot to other water sources, and the issuance of special water rights granted to its users. The first issue 
was clearly the most controversial, and in retrospect most relevant one based on the initiatives reviewed in section 4.1.

\subsection{The European Union's Water Framework Directive (2000)}

This piece of European legislation is by its own means the most relevant water policy initiative of the last 20 years, perhaps the most advanced international initiative based on world standards. Its mandates include significant changes of focus in areas like water pricing, ecological objectives, political processes, public participation, and a new approach to water water planning. It also includes the transition waters (estuaries) and the coastal waters, a fact that has created serious jurisdiction problems in Spain and the realisation of noteworthy scientific gaps in their understanding. For Spain, as well as most other UE countries, WFD implies a rebalancing of priorities from ensuring water supplies to all economic users to improving the ecological status of all water bodies. To achieve this overarching objective, a program of measures, included in new water planning documents, that passes the test of cost/ effectiveness (not cost/benefit) must be approved for all European water demarcations (main watersheds) in 2009. The general goal is that all the surface and groundwater bodies should achieve the good ecological status by 2015. Countries finding unsurmountable difficulties to meet quality standards of heavily modified water bodies must file permissions to the European Commission to obtain derogations in the time schedule (two potential extension to 2021 and 2027) or even to downgrade the targets of good ecological health, even to the point of improving it at all.. They must provide cost benefit analyses demonstrating the fact that meeting the normal standards would entail disproportionate costs. Once the WFD entered into force, no single issue related to water resources would remain uneffected by one or another provision of the WFD (Menéndez-Prieto, 2008; Del Moral, 2008; Barreira, 2008).

\subsection{The 2001 and 2004 Laws of the National Hydrological Plans}

These two laws approved and repealed a major inter-basin water transfer project, the socalled Ebro water transfer (Arrojo, 2007; Albiac et al. 2007). While many other initiatives approved in the 2001 NHP were maintained in the 2004 NHP and have already been partially implemented (for example, the NHP still includes the construction of about one hundred new large dams), the Ebro transfer epitomizes the breakdown of 
consensus of a century-old mode of thinking, planning and executing water policies. By all means the Ebro transfer was a flawed and extremely expensive project. And yet the scarcity problems along the Mediterranean coast from Catalonia to the Eastern coas of Andalusia have not been solved to the extent most studies indicate. In Catalonia, voices to reactivate the project of transferring water from Rhône are being raised in response to the severe drought in the beginning of 2008. The Ebro transfer is still demanded by politicians and users along the Mediterranean arc. However, the implications of the approval and subsequent repeal of such a big project go beyond the discussion of alternative plans to solve water problems, however important the beneficiary regions may be. It tells about the inability to create bipartisan agreements on issues that transcend the 4-year political periods. Furthermore, it paved the way to devolve competences to the Autonomous Commmunities on inter-community basins that had been granted to the Central Government (Spanish Government) in the 1985 Water Law, and originated in the the creation of the Ebro basin agency in 1926.

As recent as in 2007, the approval of the reform of the Autonmous Statues of Catalonia, Andalusia, Aragon and Valence consolidated the power of the regional governments on water affairs. One consequence of this devolution process is the transfer of competencies from Madrid to Seville (Andalusian capital) of the management of Guadalquivir basin, even though this basin includes area from two other Autonomous Communities. It should be noted that some of these provisions have been brought to the Constitutional Court (the Spanish equivalent of the American Supreme Court) for being in potential breach with the Constitutional consideration of inter-community basins as being a national jurisdiction. It is ironic that some of these appeals brought to the Constitutional Court have been filed by socialist regional (autonomous ) governments, against the Statutes of Autonomous regions also controlled by the socialist party too. In other words, the water issues override the limits of the political parties.

In 2004, the Government that brought to the legislative the repeal of the Ebro water transfer soon approved program AGUA ${ }^{1}$ (acronym in Spanish of the Initiative for Water Management and Utilisation). AGUA was meant to replace the future supplies of

\footnotetext{
${ }^{1}$ AGUA means water in Spanish.
} 
the transfer by twenty large seawater desalination and waste water reclaim plants. In the final mounths of the Government term, very of these plants have been built and become operative. In total only 214 million $\mathrm{m}^{3}$ of desalination capacity out of the 700 planned for the 2004-2008 became operative. Some of the planned plants are strugling to sign firm contracts with a future customers, totalling a demand that justifies size and capacity So, if history repeats itself, the turnout of the 2008 election in March will dictate whether AGUA continues or the Ebro transfer is rescued.

\subsection{Miscellaneous initiatives: The Guadiana program, water banks, new planing criterions and the programmes of measures.}

Less important initiatives, like the Guadiana program, the set up of water banks and the new criterions for drafting the programmes of measures issued by the Minustry of the Environment will be discussed in the fourth section, covering four case sudies that look at different angles of water policy in Spain in 2007.

\section{Drivers of change}

Four main drivers of change are giving rationale and momentum to the most recent policy initiatives. First is the the widespread recognition that many water bodies are severely deteriorated. It is beyond dispute that restoring water quality is a formidable task that requires large investments, a better administration, and a great deal of participation and education. Second, water demand still grows insatiably, especially where resources are scarce. Economic development and growth, the construction boom, the tourist sector and a competitive export-oriented agricultural sector jointly contribute to worsen the already polluted water environments. Third, the increasingly undisputable fact that climate change poses serious challenges for the Iberian peninsula. Most models predict larger evapotranspiration, lower and more unstable precipitation regimes, and lower rivers runoff. Agricultural demand will likely to grow, adding further pressure to the catchments and supply systems. And fourth, the Common Agricultural Policy has shifted the support measures from production incentives and specific sectorial programmes to completely decoupled support. Farmers are now completely free to grow the crops they want. Connected to the influence of agricultural policy is the final result of the WTO trade round in order to decrease the import barriers which today have most developing 
countries to export their agricultural products to the EU (and to Spain). The results of the WTO agreements may have a relevant impact in the ecnomic feasibility of a good number of the current Spanish crops today mainly exported to the EU. Finally, the European Commission mentioned in its report 'Health check of the CAP' the objective to ensure a sustainable use of water resources (EC 2007). As we will review below, none of these drivers lacks factual and scientific support.

The reports of Article 5 submitted by Spain to the EC in 2007 (MMA, 2007) contain numerous and updated data proving support to the first two drivers. Schmidt and De Stefano (2008) identify the reasons behind the bad ecological quality of the main river basins. For decades, industries, animal feedlots and cities have spilled untreated water to rivers and natural waterways, or let it filter to aquifers. Furthermore, MMA (2007) projects that by 2015 most basins will see their main parameters worsening or stabilising at best. Groundwater quality is experiencing similar trends. The quality of drinking water is diminishing at alarming rates, just as we see two digit growth rates of the consumption of bottled water.

Water demand projections are equally worrying. Iglesias et al. (2007) estimate that agricultural water demand will increase by 10 to $30 \%$ because of global warming. A recent study of crops' evapotranspiration in the Guadalquivir basin ${ }^{2}$ (with 880,000 hectareas of irrigated land) show that crops' water demand may range from 3.45 and 5.3 billion cubic meters depending on whether spring and summer are wet or dry (Aquavir, 2006). However, the economic feasibility of this demand will depend on factors as the previously mentioned future WTO agreements and on the implementation of the WFD principle of full cost recovery. Spanish irrigated agriculture has been heavily subsidized in the past. The range of variation of crops' demand in the Guadalquivir is equivalent to the urban consumption of 30 million people in one year. However, most analyses show that per capita consumption is stabled in Spain (MMA, 2007), and the economy's growth is increasingly becoming decoupled from water use growth.

Compounding the growth of water demands, the MMA (2007) projects that runoff in most basins will be lower and more unstable. The impacts on the mountain areas

\footnotetext{
${ }^{2}$ It includes Guadalete and Barbate Andalusian basins.
} 
and the snow regime will severely modified, if the findings on the Rhône (Bravard, 2008) are applicable to the Iberian basins. In addition, according to MMA (2007), runoff regimes will become more unstable and prone to extremes. The consequences for the managing of reservoirs are that security levels for laminating floods may need to be increased, reducing in turn the storage capacity. The recognition of of these processes and implications is landing in official documents and political statements alike, becoming a motto for raising awareness and becoming a rationale for numerous initiatives. As dubious as the MMA reports may be, they indicate the major trends and convey information that before compiling the reports was dispersed or simply ignored.

\section{Changes in the agricultural water demand}

The fourth driver is the reform of the EU agricultural programmes, and its indirect implication on agricultural water demand. Up until 2003, support granted to the farm industry by the Common Agricultural Policy was based on price support mechanisms or per hectare direct payments. As a result of both, farmers' incentives to grow certain crops (virtually all except the fruits and vegatables) were driven by relative subsidy differences as well as quotas and other acreage limits. Examples of these distortions are numerous and telling. From 2003 on, farmers are more free to grow the crops they wish and their decisions far more influenced by prices and food demand. Furthermore, crops which were rarely irrigated ten years ago, like olive oils and vineyards, now occupy 800,000 hectareas of irrigated acreage. The interesting feature of these crops is that they require lesser water applications and that endure tougher conditions of water stress than the crops experiencing decline, like sugar beets, cotton, corn and tobacco.

This shift of cropping patters has huge implications for many water stressed basins. One is that the opportunity cost of water is now more transparent and connected to farms' different profitability. As a result of this, farmers are more opened to market signals and less relunctant to exchange water rights than 10 years ago (Garrido et al, 1997). Secondly, in many areas farm water demand is now more flexible to accommodate to the actual hydrological conditions. Flexible allocation and drought contingent programmes can find more room within the farming sector to face water scarcity periods. While water exchanges so far have moved small amounts among different users, they 
represent a qualitative difference with profound consequences for the future. Third, the water footprint of olives and vineyards altogether is 3.6 billion cubic meters, whereas both crops occupy 3.6 million ha; where as cereals' internal footprint is 6.3 billion c.m. and acreage is 6.8 million ha. (Rodríguez Casado, 2008). Varela-Ortega and Garrido (2008) show that the irrigated acreage of corn and other field crops, like cotton and sugar beet, are losing importance in favour of more adapted crops to the Spanish climate.

Farms product trade in Spain is also becoming more integrated. Novo (2008) has evaluated the volume of water and its economic value 'virtually' traded just with the commerce of grains and cereals in Spain. She shows net imports of virtual water trade with cereals were 5 billion c.m. and grew steady from 1997 to 2005 , totaling 9 billion c.m.

The technological and engineering factors connected to farmers' water use are also becoming crucial. At the irrigation district level, the Government has completed modernization and rehabilitation projects in old districts totalling 1.3 million hectares (Barbero, 2005). In most cases, farmers have been requested to pay up to $50 \%$ of the cost, although were given preferential treatment to give it back in 50-year loans. These projects entailed in many cases a complete refurbishing of the irrigated districts, converting $19^{\text {th }}$ century design into $21^{\text {st }}$ infrastructures. At the farm level, drip irrigation technology is now the commonest in Spain, occupying more than 1.3 million hectares in 2005.

In terms of labour use, agriculture has shown a stable downward trend as figure 1 attests. In terms of macroeconomic profitability, Spanish agriculture has experienced a marked process of capitalisation, that has been followed by reduced margins and tighter economic conditions. While the index of animal and plant prices at farm gates reached 107.6 and 106.2 in 2006 (with 100 in 2000), the indexes of farm input prices have grown to 133 (fuel and energy), 145 (nitrogen fertiliser) and 123 (farm capital goods) (MAPA, 2007).

\section{ABOUT HERE FIGURE 1}

The value of food products obtained in irrigated land has kept growing in constant prices since year 2000 as shown in figure 2. The figure plots total agricultural output 
obtained in irrigated land and dry-land (evaluate in billion $€$ of 2000), as well irrigated and dry-land acreage (in million hectares).

ABOUT HERE FIGURE 2

\section{Changes in social discourse and the breakdown of consensus}

One of the strongest forces, and yet poorly understood and analyzed, underlying Water policy reform in Spain has been the breakdown of century-long consensus (del Moral, 2008). Up until 1994, when the first failed attempt to pass a Law of National Hydrological Plan, civil engineers had provided the intelectual leadership and tehcnical capacity to design and execute water plans. In the last 10 years, many other professional and scientific fields have become as much, if not more, influential in the most controversial discussions. In particular, hydrogeologists, agronomists, chemists, ecologists, economists and other social scientists now have more prevalence than civil engineers, and are increasingly filling the vacants in basin agencies and top management positions in the Environmental departmentos of both regional and national governments. In this respect, the Spanish situation is similar to the one described by Dooge (1999) and by Allan (1999) in many other countries.

The consequences of opening the 'water resources' agenda to numerous professions cannot be sufficiently stressed. First, while civil engineers focused almost exclusively on water quantitities and flows, the importance of water quality and river systems ecological status gained prevalence with the enforcement of the WFD. Droughts and floods were soon joined by reports of ecosystems' destruction and water pollution in the media, changing the view of the general public and redirecting many politicians' dicourse (del Moral, 2008).

The discussions and debate about 2001 NHP gave rise to another equally important breakdown of consensus. In this case, regional disputes over transboundary rivers became explicit and turned into political ammunition. Although the management of inter-community water resources is, according to the Spanish Constitution, a national jurisdiction, some Autonomous Communities claimed area-of-origin rights to question 
the grand Ebro transfer scheme. The beneficiary regions, in turn, claimed that intercommunity basins were a national jurisdiction and inter-basin transfers were strategy projects for the whole country. While the 2001 NHP was stopped soon after Socialist Administration came into office in 2004, conflicts subsided but did not disappear. For one thing, the region of Castille-La Mancha demanded that Tagus-Segura transfer should be eventually phased out, on the basis that the region is in need of the water resources that is transferred annually to the Segura basin. Furthermore, the 2004 political term opened a period of political discussions in Catalonia, Andalusia, Valencia, Castille-La Mancha, Aragón and Basque Country among others, to draft and approve new Autonomous Statutes. These statutes represent the cornerstone of the political autonomy the Autonomous Communities and mark the division line between the Central and each AC's competencies. First was the Catalonian Autonomous Statute, and soon came some others'. The implications of the redefinition of the Autonomies' regimes for water the management of inter-community river basis are doubtful. On the one hand, all new Statutes define to a larger or smaller extent new competencies over inter-community basins; the Andalusian being as deep as to declare in article 51 that the region "has exclusive competencies over the Guadalquivir resources that flow within its territory and do not affect other Autonomous Community", adding that "[those competencies] should not affect the National Planning of the hydrological cycle, ... nor be in breach with article 149 of the Constitution", which establishes the exclusive competencies of inter-basin river basins. On the other hand, the Andalusian Statute has been brought to the Constitutional Court on the grounds, among others, the Guadalquivir provisions of her Statute breach the constitutional principles. While the Court has not pronounced itself on this issue, the Andalusian regional government has already been given competencies on the Guadalquivir and setup a regional office to manage it.

While it is still soon to ascertain the impacts of this process of devolution, a prudent judgment would indicate that the role of the Central government on intercommunity basins has been diminished. Water policy is increasingly a regional policy, and regions, with the eventual support of their Autonomy Statutes, will surely develop their own legislative initiatives. 


\section{Case studies}

Against the dynamic process of institutional, environmental and economic changes summarised above, there are processes ocurring at a lower scale that perhaps better exemply the profound transformation of Spanish water policy. In the first case, we review the way economics has recently permeated many facets that not long ago were totally devoid of economic dimenssions. In the second case, we look at the way decades-long problems of groundwater overdrafting have been approached.

The following case studies are proposed to provide a complementary view of the major trends discussed above. In the first case, focusing on the increasin role of economic instruments, we wish to illustrate how distant were water allocation and management in Spain from any sense of economic rationality. In this we integrate notions like scarcity values, cost recovery rates, externalities and non-market values, together with rents and profit accruable from productive uses. We wish to show with this example that little progress was made since 1989 in the economic area until the 1999 WL reform and the WFD of 2000 recognised that water policy could not progress without the support of economic instruments. With the second case study, looking at succession of attempts to tackle the most pressing problems related to groundwater use, we wish to illustrate how statutes, however clear and sound, fail in the absence of economic compensations, and water rights redefnition. The last case sudy, looking at the economic rationale of integrated water management, is proposed against the devolution process in the area of water management among the Autonomous communities. It shows that cooperative behavior along entire watersheds is the most cost-effective means to achieve the objectives of the DMA, and provides rationale to maintain the basin perspective that Spain has had since 1926 and the DMA extents even to internationally shared river basins.

5.1. Changes in the economics of water resources, including flexible allocation instruments, voluntary arrangements, and water prices

\subsubsection{The economic analyses and evaluation of the Ebro transfer}


The project of the Ebro transfer has been thoroughly documented (Arrojo, 2003; Albiac et al. 2007 ). A grand scheme of inter-basin connections from the Ebro delta, Northeast to Barcelona (with about 200 million $\mathrm{m}^{3}$ of capacity, and $150 \mathrm{~km}$ long) and Southwest to Almeria ( 800 million $\mathrm{m}^{3}$ of capacity and almost $800 \mathrm{~km}$ long). The project was made public by the Government in 2000, giving rise to five intense years of discussions, debate, street demonstrations and political fight. According to most analysts, including those contracted by the own Government (Universidad Politécnica de Cartagena, 2001), the project had three major flaws. First, it disregarded the mass balance of the delta and the low Ebro ecosystems'. Second, it was based on shaky evaluations of the demands it was meant to supply, primarily farmers relying on overexploited aquifers or insufficient water sources. And third, its cost benefit analysis (CBA) was fatally wrong. Different teams reached very negative CBA results (San Martín \& Pérez Zabaleta, 2002; Arrojo, 2003; Albiac et al., 2007; Hanemann, 2003 ; Garrido, 2003). Linked to this was the fact that the option to add additional supplies in the most remote locations using desalination was not considered in the analysis of alternatives. The project's costs evaluation was flawed, too, according to all external reviewers (Pérez Zabaleta et al. 2003; Arrojo, 2003). So were the criterions used to distribute the costs to the the project costs, which considered an average rate to all beneficiaries averaging out the project costs. In terms of financing and designing grandwater works, the Ebro project still represents a landmark in wrongdoing and poor design.

\subsubsection{The Article 5 Spanish report to the European Commission}

WFD's Article 5 establishes that each Member State should carry out for all its river basins (1) an analysis of its characteristics; (2) a review of the impact of human activity on the status of surface waters and on groundwater, and (3) an economic analysis of water use (see MMA, 2007). This represents massive study for the whole country, and a completely new approach to the inherited criterions with which water statastics were collected and recorded. Spain submitted its report and was given a good mark by the EC (72 points, rank $6^{\text {th }}$ out of 27 member States; EC, 2007). The findings of these reports cannot be sufficiently stressed. They pertain to the evaluation of cost-recovery rates in the agricultural sector - very close to $100 \%$, simply because the costs are evaluated with inadequate amortissation rates of the infrastructure. They show that about 50\% 
agricultural water uses has less than 2 cents of euro per cubic meter of profitability. But groundwater users incur costs that are five to ten times the tariff paid by farmers using superficial resources. The reports also illustrate how cheap is urban water in most cities in comparison to other EU countries (a factor of 2 with respect to the mean, and 3 with respect to Germany, Denmark or Sweeden, to name a few). At present industrial and urban water rates (see MMA, 2007), sewage treatment can only ensure filtering, oxygenation and decantation. In the Metropolitan city of Seville only $20 \%$ of urban wastewater undergo tertiary treatment, and most other medim to large cities do not outperform Seville's.They show that the tendencies for 2015 in most water quality parameters will either stabilise or worsen, giving little hope for improvement at least in the business-as-usual scenarios.

The Article 5 report has hree main political implications. First, water prices will need to be significantly raised for all water services. This is because pressures and impacts from water services have still significant deleterious effects on the ecological status of most water bodies, which will need to be addressed with more expensive water treatment and pollution abatement. Second, out of all agricultural water uses, about 30$40 \%$ is still uncompetitive, despite the significant growth in technology adoption and the intense pace of districts rehabilitation of the last ten years. As we review below, incentives to initiate water exchanges will grow with the growth of demands and tighter water balances, exacerbated by the enforcement of the programmes of measures (in pursuant to WFD article 11).

Despite its drawbacks, resulting mainly from the exercise of compiling information that was never collected with the specific Article 5's purposes, the report provides a clear picture of all surface water uses, pressures and impacts mapped for the whole country, but does not fill the gap of knowledge with groundwater resources. The value of this information is still dubious, but in the medium term, it will likely help redefine notions like 'uses of general interest' or 'structural deficits' in the most arid or semi-arid basins. Perhaps subtler than the others, the third major implication is due to the fact that so much information, properly organised and readiy accessible, has been generated. Policy actions can now be easily judged on all accounts by the general public, media and the academic community. 

recovery prices'

Water tariffication is one of the cornerstone of the WFD (see Article 9). And yet, little is known about the extent to which water charges will 'take into account the environmental and resource costs' in addition to the financial costs. The EC seems to follow the principle of averted environmental costs, which in general generates very narrow and limited definitions of environmental costs. Even more difficult is the notion of resource cost, a concept that needs functioning water markets to become apparent and self-evident. Ironically, if water trading becomes a common practice there will not be need to incorporate them in the charges.

In the area of irrigation, by far the largest water consumer in Spain and perhaps the most vulnerable sector to higher water prices, it remains to be seen whether article 9 is applied in its fullest extent. Molle \& Berkoff (2007) edited a book that, as a whole and based on numerous case studies around the world, concludes that the role of water pricing in the agricultural sector should be downgraded. In Spain, most studies coincide in identifying a severe income effect and little reductions in water use resulting from water charge increases within the range of political feasibility (Berbel et al.2007; Garrido \& Calatrava, 2007).

\subsubsection{The creation of 'water banks' and the increasing occurrence of voluntary water exchanges}

It was stated in the first section that, although the Water Law reform opening the era of water makets was enacted in 1999, the first experiences took almost seven years to occur. The Law opened two routes to enable right-holders to lease out their rights either to the basin authorities or to another user. The simplest way just takes an agreement of two right-holders and their decision to file a permission to formally exchange the right. The basin agency has 30 days to respond and, unless major technical, environmental or thirdparty difficulties are encountered, the petition will be granted. Very few, albeit significant, exchanges have been reported.

Consider the case of a big commercial farm in Almería (Southeast) that purchases rice fields in the marshes of the Guadalquivir basin, $300 \mathrm{~km}$ away from Almeria in a 
different basin. As a water right-holder, it files a request to transfer its water rights linked to the rice paddies to Almeria, using an inter-basin water transfer that connects the headwaters of the Guadalquivir with another basin (the Negratin-Almanzora aqueduct). This sale was approved despite the potential third-party effects of water resouces that, in the absence of the transfer, would have flowed to the Atlantic ocean along the Guadalquivir river along $300 \mathrm{~km}$.

In another case, an irrigation district in the Tagus basin leases out all its water rights to a set of users in the Segura basin, using again another inter-basin aqueduct (the Tagus-Segura aqueduct). The revenue generated for the farmers by the contract is larger than the value of the crop farmers would have produced in a normal year (Garrido, 2006). The agreement was especially profitable because of two reasons: first, the district was undergoing a rehabilitation project to reduce the extremely large water allotments, which were transferred in full in the sale; secondly, as the rehabilitation project was being implemented, farmers would have hardly been able to irrigate their fields during the season for which the rights were transferred. Farmers leased-out their full allotments from headwater resources that had been used for years very inefficiently to users located in another basin.

The last case involves a subtler exchange that entailed no water transfer at all, but the obligation to maintain the minimum levels of key reservoirs. These levels are statutorily connected to the management of the Tagus-Segura aqueduct, so that the amount of resources that can be transferred in each year is conditioned on the state of the reservoirs at given dates. Through the purchase of water rights of users serviced from them, the purchasers could effectively increase their rights to transfer resources across the basin, simply keeping the levels above the minimum thresholds.

These three large-scale transfers illustrate the type of exchanges that will be more frequently requested. In general, they serve the purpose of moving water from the South central plateau to the Southeast. For the moment, basin authorities and the Ministry of the Environment have been permissive in granting these transfer requests. But once the thirdparty impacts are identified and evaluated, they will perhaps become more difficult (see Colby, 1990, in her seminal work, on water trading and its institutional impediments as 
proxies of environmental taxes). Colby's thinking also fits with the fact that the

government of Castille-La Mancha, the main area-of-origin in most exchanges, are erecting institutional barriers to prevent users located in their territories from selling water to others in adjacent Autonomous Communities.

The second route to enable water exchanges is by means of the so-called water banks or exchange centres. Not strictly an office or agency, these centres are hosted, run and located in the basin agencies themselves. Garrido (2007a \& 2007b) show that centres are much more efficient means to promote water exchanges, because all sorts of reasons, including transparency, control, avoidance of third-party effects and market activity and scope. And yet, the experience so far has been limited to the Jucar, Segura and Guadiana basins. Since these water centres have been primariy used to tackle severe problems of overexploitation of groundwater resources, we review them in section 5.2.

\subsection{Tackling most pressing problems with intensive use of groundwater} resources

Since the enactment of the 1985 Water Law, that included special provisions to tackle problems of overexploited aquifers, there have been at least four major initiatives to manage groundwater resources. In short, these were (a) the declaration of overexploited aquifers and the mandate to enforce regulations and implement management plans; (b) an EU agri-environmental program, only applicable to Aquifer 23 in the Guadiana Basin, with subsidies to farmers curtailing their water consumption; (c) the use of inter-basin transfers, both in the case of the Southeast coastal areas and in the Upper Guadiana; and lastly, (d) The Especial Plan of the Upper Guadiana (PEAG, Spanish acronym), and the creation of exchanging centres in the Segura, Jucar and Guadiana basins (see Llamas \& Martínez-Santos, 2008; López-Gunn, 2008; Llamas \& Custodio, 2003; Varela-Ortega, 2007).

Varela-Ortega (2007) traces the history of the emblematic Aquifer 23 in the Southern Castillian plateau, linking the ups and downs of its piezometric levels with the first three rounds initiatives just mentioned. Clearly, option (a) failed; option (b) succeeded, but the financial cost was very high; option (c) failed because option (b) was not sustainable. At the end, the PEAG was approved in 2007 with a total budget for 20 
years of 5 billion euros (equivalent to proposed Ebro transfer) and part of its subprogrammes are now operating, though in PEAG the basin would be end up reducing a meagre 200 million $\mathrm{m}^{3}$.

Underlying these initiatives, but undermining them too, was the recognition that tens of thousands users in vitually all basins had no legal rights or concessions to the groundwater resources they have been tapping for years. Any effort to reduce total extractions in the overdrafted hydrologeological units had to be accompanied by the closure of the 'alegal' or 'illegal' users. As López-Gunn (2008) has made clear, so far all attempts have failed, and any reduction of total extractions has come from the efforts made by both legal and illegal users.

In 2005 it was clear by all managers, analysts and users that something new had to be given a chance. The option to use buyouts of water rights, permanent or temporal, gave rationale to the setup of exchanges centres (centros de intercambio in Spanish). We will review the different approaches taken in the Jucar and Guadiana. In the Jucar basin, the Offer of Public Purchase (Oferta pública de adquisición de derechos, OPA) was targetted to farmers tapping groundwater resources near the Jucar's headwaters river banks. Its objective was to increase the piezometric levels in Castille-La Manche to ensure that Jucar flows to the Valencia region increase from historical lows. Farmers were given the option to lease-out their rights for one year in return of a compensation ranging from 0.13 to 0.19 cents per $\mathrm{m}^{3}$, the variation depending on the distance of the farmer location to associated wetlands or to the river alluvial plain. The OPA was launched in two rounds, the first being disappointing based on the farmers response while the second had more success. The purchased waters served the unique purpose of increasing the flows, enabling more use downstream in Valencia. But the OPA did not have not any specific beneficiaries dowstream, other than the increase of flows.

The OPAs of the Guadiana followed a completely different approach and were meant to address serious problems of overexploitation in the Upper Guadiana. As stated before, the OPA formed part of a more ambitious program of aquifers' recovery, called the PEAG. The Guadiana's OPA made offers to purchase permanent water rights to groundwater, paying farmers between 6,000 to 10,000 euros per hectare of irrigated land. 
Note that, since these farmers had seen their allotments reduced in the last years, what the Guadiana basin was truly purchasing from the farmers was about 1500 to $2500 \mathrm{~m}^{3} / \mathrm{ha}$, so 2 to 4 euros per $\mathrm{m}^{3}$. The Guadiana basin agency has the objective to 'purchase' the water rights of 50,000 hectares of irrigated land, and is budgeting 500 million euro for the whole plan. A marked difference with the Jucar's OPA is that the Guadiana exchange center will transfer part of these rights to other farmers (growing vegetables) and to the Autonomous Community of Castille-La Mancha. The Guadiana basin will grant less rights than it has purchased, allocating the difference to wetlands and to increase the piezometric levels of the aquifers. One subtlety of the Guadiana scheme is the fact that, while farmers entering the program must surrender their private rights (honoured because they were in the catalogue of private waters before the 1985 water law was enacted), those that gain access to them will be granted 30-year 'concession' rights (which is more attenuated property than the others). So the Guadiana operation had this other dimension that in the long term will imply that the basin agency has more users with 'concessions' than with private rights.

Livinsgton and Garrido (2004), reviewing the US and Spanish experience with overexploited aquifers, hypothesised that OPAs such as those of the Jucar and Guadiana would be the only feasible solution. What these authors overlooked was that OPAs would serve also the purpose of water reallocation, entitling government agencies with water rights, that in turn would allot to other users. A question that has not been addressed in the Guadiana case is the price that will be asked to the new users, and whether the exchange centre will incur losses or be able to recoup the costs of the purchase.

\subsection{The cost-effectiveness rationale of programmes of measures ${ }^{3}$}

Formatted: Bullets and Numbering

Through this third angle, we review the main breakthrough of the Cidacos Pilot project. This project, completed in 2003, was promoted by Spanish institutions to develop a conceptual framework for the application of WFD's article 11 definitions of 'programmes of measures'. Gómez and Garrido (2007) summarised the rationale of the use of cost-effectiveness in the selection of the programes of measures that are least costly. Consider the parameter of water flow in a given river, that is divided in three

\footnotetext{
${ }^{3}$ This section borrows from Gómez and Garrido (2007)
} 
strechtes. Obtaining Good Ecological Status (GES) implies that rates of flow must be increased by, say, 20, 80 and 100 litres/second respectively in the upper, middle and lower stretch of the river. In figure 3, marginal costs curves are represented against rates of flow in the horizontal axis, for the three stretches.

ABOUT HERE Figure 3

SSSource: Gómez \& Garrido (2007)

One would ask whether the above approach is cost effective. Since stretch I is upstream stretches II and III, it would perhaps be reasonable to go beyond the required level in strecth I (20 l/s) and perhaps move the marginal cost curves in stretches II and II to the right (a reduction of costs). In Figure 4 we represent the option to increase the standards in streches I and II, and the resulting cost reduction in strecth III. If the overall cost can be reduced by going beyond the standards in some stretches, the most costeffective programmes of measures will focus more on the upper reaches than downstream.

\section{ABOUT HERE Figure 4}

What the Cidacos project showed and put into practice goes beyond this simple reasoning. The project designed a cost-effective programme of measures, mapped those in the Cidacos basin, linked them with the different agents (users and pollutants) and, in a final stage, put the programme open to discussins in hearings following the WFD mandate about public participation. The general public of Navarre (the region of the Cidacos) participating in the discussions understood the whole rationale of the programmes and accepted that differential treatment of pollutants along the basin. They even agreed on financial scheme and on criterions to share the costs. This case study was taken by the EC and integrated in the WATECO guidelines, jointly with other pilot studies, that were met to help member states to conduct the economic analyses mandated by the WFD, including the selection of cost-effectiveness analysis of programmes of measures. In Spain, the Cidacos project inspired tens of tenders put out by the basin agencies to conduct similar studies. 


\section{Drawing useful lessons from the Spanish example}

This paper has summarised the major developments and challenges of the recent history of water policy in Spain. The following lessons can be drawn from it:

a) Large water projects are not the solution to unsustainable water uses or enhance water supply reliability. More flexible alternatives (with and without technologies), that ensure some screening of the beneficiaries and a sound financial scheme are prerrequisites for giving green light to grand water works.

(b) Flexible and adaptable solutions, that rely on technlogies, infrastruture and demand management instruments are more complex and require multiple standpoints and longer approval periods. The context must ripen before innovative schemes get through. In general, once crises, major landmarks or thrusts occur it is easier to plan and implement complex solutions.

(c) The actual costs of supplying water at subsidized prices multiply spilling over other users, the taxpayer and the environment, especially when scarcity becomes acute. Cheap water granted in the form of concessions create perceptions in their holders of being 'entitled' to water resources. When trading systems are established, extraordinary rents will be created by those selling the water. While many would find this offensive, a continuous functioning of the market will tend to erode the rents.

(d) Rigid, hierarchical and top-down planning models fails when water hegemonic thinking and political coalitions break down; all the more if there are also regional disputes.

(e) Accesible information, science-based decision making and public participation are key elements to breakthrough entrenched and adversarial positions;

(f) Innovative water policies require strong budgets, sound finance and equitable burden distribution. 


\section{References}

Aquavir (2006). Superficie de los Cultivos de Regadío y sus Necesidades de Riego, en la Demarcación de la Confederación Hidrográfica del Guadalquivir. Sociedad Estatal Aguas de la Cuenca del Guadalquivir, SA. y Empresa Pública Desarrollo Agrario y Pesquero, SA.

Albiac, J.; Uche J.; Valero A.; Serra L.; Meyer A.; Tapia J. (2003) The economic unsustainability of the Spanish national hydrological plan. International Journal of Water Resources Development 19(3): 437-458.

Allan, J. A. 1999. The Nile Basin: evolving approaches to Nile water management, Paper presented at the Conference on Water Quality, convened by the International Institute of Water Quality Sciences, Jerusalem.

Ariño, G. \& Sastre, M. (2008) Water Sector regulation and liberalisation. In Garrido, A and Llamas, M. R. (Eds.): Water policy in Spain, Resources for the Future, Washington, D.C. (In preparation).

Arrojo, P. (coord.) El Plan Hidrológico Nacional a dabate. Bakeaz, Bilbao, 2001.

Barbero, A. (2005). The Spanish National Irrigation Plan. Paper presented at $O E C D$ Workshop on Agriculture and Water: Sustainability, Markets and Policies November 14-16: Adelaide, South Australia

Barreira, A. (2008): "Public participation in developing and improving water governance", In Garrido, A and Llamas, M. R. (Eds.): Water policy in Spain, Resources for the Future, Washington, D.C. (In preparation).

Berbel, J., Calatrava, J. and Garrido, A., (2007). "Water pricing and irrigation: a review of the European experience" In F. Molle, J. Berkoff (eds). Irrigation Water pricing Policy: The Gap Between Theory and Practice. CABI, IWMI.

Bravard, J.-P. (2006). Combined impacts of development and climate change

on the Rhône river (Switzerland, France). Paper Presented at the $V^{\text {th }}$ Conference of the International Forum of Water Policy, Banff, Canada. September. 
Colby, Bonnie G. (1990) "Transactions Cost and Efficiency in Western Water Allocation." American Journal of Agricultural Economics 72:1184-1192.

EC (2007). Towards sustainable water management in the European Union- first stage in the implementation of the Water Framework Directive 2000/60/ec. Communication from the Commission to the European Parliament and the Council, Brussels, 22.3.2007. COM(2007) 128 final

Dooge, J.C. I. .1999. Hydrological science and social problems. Arbor 646(October), 191-202.

Embid Irujo, A. (2008). The Foundations and principles of Modern Water Law. In Garrido, A and Llamas, M. R. (Eds.): Water policy in Spain, Resources for the Future, Washington, D.C. (In preparation).

Garrido, A., Iglesias, E. and Blanco, M. (1996) "Análisis de la actitud de los regantes ante el establecimiento de precios públicos y de mercados de agua.". Revista Española de Economía Agraria 178: 139-162.

Garrido, A. (2007a) "Water markets design and experimental economics evidence". Environmental and Resource Economics 38(3): 313-330, $2007 \mathrm{a}$.

Garrido, A. (2007b) Designing Water Markets for Unstable Climatic Conditions: Learning from Experimental Economics. Review of Agricultural Economics 29(3): 520-530. .

Garrido, A. (2003) “An Economic Appraisal of the Spanish National Hydrological Plan”. International Journal of Water Resources Development 19(3): 459-470. 2003

Garrido, A. and Varela-Ortega, C. (2008). Economía del agua en la agricultura e integración de políticas sectoriales. Panel de Estudios. Universidad de SevillaMinisterio de Medio Ambiente.

Garrido, A. and J. Calatrava. (2008) “Trends in Water Pricing and Markets". In Garrido, A, and M.R. Llamas (Eds.) Water policy in Spain. Resources for the Future, Washington, D.C. In preparation 
Garrido, A, y M.R. Llamas (Eds.) Water policy in Spain. Resources for the Future, Washington, D.C. 2008, In preparation

Garrido, A. (2006) “Analysis of Spanish Water Law Reform” In B. R. Bruns, C. Ringler, R. Meinzen-Dick (Eds). Water Rights Reform: Lessons for Institutional Design, Washington, D.C.: International Food Policy Research Institute, pp-219-236.

Gómez, C.M. \& A. Garrido (2007). Cost Effectiveness Analysis for the WFD. In Pulido (ed). Economics in Water Management Models. Applications to the EU Water Framework Directive. SPRINGER. (in preparation.)

Iglesias, A., Moneo, M., Garrote, L. and Flores, F. (2008): "Drought and water scarcity: current and future vulnerability and risk", In Garrido, A and Llamas, M. R. (Eds.) Water policy in Spain, Resources for the Future, Washington, D.C. (In preparation).

Hanemann, W.M. (2003) c. Economics: Findings and Recommendations in Horne (ed). A Technical Review of the Spanish National Hydrological Plan (Ebro River Out-OfBasin Diversion). Fundación Universidad Politécnica de Cartagena, Spain.

Llamas, R. y E. Custodio (Eds). Intensive use of groundwater: challenges and opportunities. Balkema Publishing Company, Amsterdam, 207-221 2002.

Llamas, M. R. (2005) Los colores del agua, el agua virtual y los conflictos hídricos. Revista de la Real Academcia de Ciencias Exactas, Físicas y Naturales 99(2), 369.

Livingston, M.L. and Garrido, A. "Entering the Policy Debate: An Economic Evaluation of Groundwater Policy In Flux". Water Resources Research, Vol. 40 ¡12). WS12S02, 2004.

MAPA (2007) Anuario de Estadística Agroalimentaria. Ministerio de Agricultura, Pesca $\mathrm{y}$ Alimentación. (http://www.mapa.es/es/estadistica/pags/anuario/introduccion.htm). Consultado el 25 junio y el 17 agosto. 
MMA (2007) El Agua en la Economía Española: Situación y Perspectivas. Informe Integrado del Análisis Económico de los Usos del Agua. Artículo 5 y Anejos II y III de la Directiva Marco del Agua. Ministerio Medio Ambiente. Madrid.

MMA (2007) Precios y costes de los servicios de agua en España. Informe integrado de recuperación de costes de los servicios de agua en España. Artículo 5 y Anejo III de la Directiva Marco de Agua. Ministerio de Medio Ambiente. 220.

MMA, 2007. Evaluación de los Impactos del Cambio Climático en España, Ministerio de Medio Ambiente, Madrid.

Menéndez-Prieto, M. (2008). Facing the Challenges of Implementing the European Water Directive to Spain. In Garrido, A and Llamas, M. R. (Eds.) Water policy in Spain, Resources for the Future, Washington, D.C. (In preparation).

Messerli, B. (2006). Mountains of the World - Water Towers for the 21st Century. Paper Presented at the $V^{\text {th }}$ Conference of the International Forum of Water Policy, Banff, Canada. September

Moral, L. del (2008) Changing Water Discourses in a Modern Society. In Garrido, A and Llamas, M. R. (Eds.) Water policy in Spain, Resources for the Future, Washington, D.C. (In preparation).

Rodríguez Casado, R. (2008) La huella hidrológica de la agricultura española. Trabajo Fin de Carrera, UPM

Sauchyn, D. (2006). Upland Watershed Management and Global Change - Canada's Rocky Mountains and Western Plains. Paper Presented at the $V^{\text {th }}$ Conference of the International Forum of Water Policy, Banff, Canada. September

San Martín González, E. y A. Pérez Zabaleta. (2002). Una evaluación económica del trasvase del Ebro según la Directiva Marco del Agua. In Del Moral, L. (coord..).III Congreso Ibérico sobre Gestión y Planificación del Agua. Univ. de Sevilla y Pablo Olavide.

Schmidt and De Stefano (2008). Major deteriorating processes of Freshwater resources and ecosystems. In Garrido, A and Llamas, M. R. (Eds.) Water policy in Spain, Resources for the Future, Washington, D.C. (In preparation). 
Varela-Ortega, C. (2007). Water And Nature: Public Policies for Groundwater Management and Ecosystem Conservation. Paper presented at the VI Agricultural Economics Congress of the Spanish Association of Agricultural Economists. Albacete, Spain, Sept. 15-17. 
Figure captions.

Figure 1. Farm Employment Trends (hired and farm operators in 1000s)

Figure 2. Total agricultural output and surface (separating rainfed and irrigated crops)

Figure 3. Cost-effective program with three independent water bodies

Figure 4. Least cost program, integrating the standards of three connecedt water bodies 